\title{
TERRORANGREBET PÅ USA OG BEKYMRING FOR KRIMINALITET
}

\section{Af fuldmæatig Susanne Clausen}

A survey from the beginning of October 2001 indicates that Danes became less concerned about crime immediately following the terror attack of September 11th. Concerns about immigrants, unemployment and other issues also declined. Only concerns over the risk of war increased. A possible interpretation of this result is that the terror attack diverted public attention, which caused normal daily worries to fade. Alternative explanations are, however, possible. The drop in concern about crime may have been due to less media focus on crime in the period just after September 11th. Alternatively, the drop in concern about crime and other issues may have been an artifact of minor questionnaire changes as the October survey included some new questions concerning people's feeling of safety in general. The addition of the questions may have caused a context effect, as Danes generally feel rather safe and these safety questions were put first in the questionnaire.

To test for a possible context effect another survey was conducted in which half of the respondents were asked the additional safety questions while half were not. A comparison of the results indicates that the additional safety questions resulted in a significant context effect. Despite this, the drop in concern over crime in early October cannot be totally explained by this context effect. The immense focus on the terror attack seems to have also contributed to the decline in the normal worries. *

Hvilken betydning havde terrorangrebet på USA for mennesker på vore breddegrader? Skabte det utryghed og bekymring? Og hvis ja, smittede bekymringen af på andre forhold, eller drejede det sig om en specifik bekymring for terror? Disse spørgsmål var udgangspunktet for den undersøgelse, som præsenteres i det følgende. Undersøgelsen besvarer spørgsmålene, men den rejser samtidig en række spørgsmål af metodemæssig karakter.

\section{Baggrund}

Siden 1985 har Institut for Konjunktur-Analyse (IfKA) undersøgt, hvad danskere bekymrer sig for. Undersøgelserne foretages kvartalsvis og har de seneste par år omfattet 1100 respondenter mod tidligere 600 pr. måling. Et af de spørgsmål, der indgår i undersøgelsen, vedrører bekymring for vold og kriminalitet.

Gennem de seneste år har der været en tydelig tendens til, at bekymringen for

* Title in English: The Terror Attack and Concern about Crime. Original in Danish. 
vold og kriminalitet er aftaget, og især i 2001 har andelen, der bekymrer sig meget for vold og kriminalitet, været forholdsvis lille. Der har således ikke siden målingerne startede i 1985 været så få, der bekymrer sig meget for vold og kriminalitet, som i 2001, jf. figur 1.

Figur 1. Andel, der bekymrer sig meget for vold og kriminalitet, 1985 til september 2001 (med statistiske sikkerhedsintervaller)

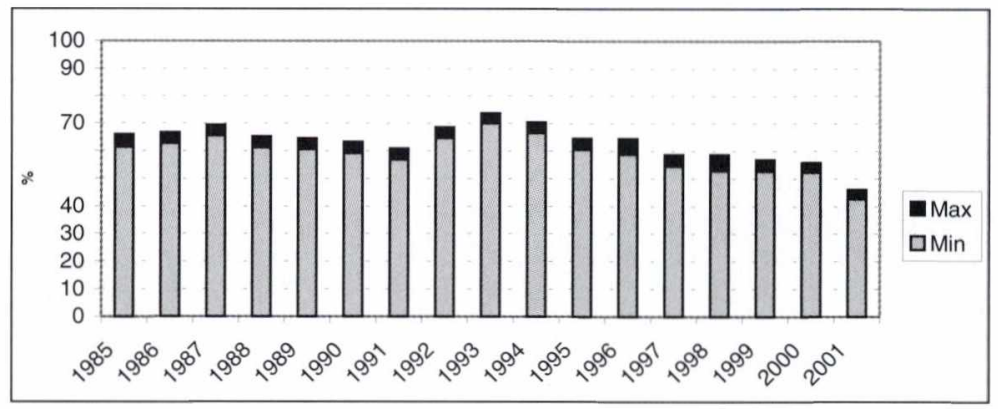

I dagene 25.-30. august blev den ordinære kvartalsundersøgelse gennemført, altså et par uger inden terrorangrebet på USA.

Med henblik på at belyse i hvilket omfang terrorangrebet på USA den 11. september har ændret danskernes bekymringsniveau, fik Justitsministeriet foretaget en separat undersøgelse hos IfKA. Denne undersøgelse, der er foretaget den 3.-5. oktober og omfatter 1015 respondenter, adskiller sig fra de ordinære ved at omfatte færre spørgsmål om bekymring. De områder, der spørges om, er Bekymring for vold og kriminalitet, Bekymring for indvandrere og flygtninge, Bekymring for arbejdsløshed, Bekymring for ventelister og Bekymring for faren for krig. Den adskiller sig endvidere fra de øvrige undersøgelser ved også at omfatte spørgsmål om tryghed ved at færdes i lokalområdet m.v., spørgsmål der ikke i øvrigt indgår i denne type af undersøgelse.

\section{Hypoteser}

Terrorangrebet den 11. september kan tænkes at have haft en eller flere af følgende virkninger:

1) Man kan forestille sig, at reaktionen på terrorangrebet har været så voldsom, at det har affødt en generel øget bekymring. Dvs. at danskere ikke bare er blevet mere bekymrede for forhold, der er relaterede til terrorangrebet eller følgerne deraf, men at en øget bekymring også ses på områder, som i øvrigt ikke umiddelbart kan antages at være forbundet med terror. Er denne antagelse korrekt, må man forestille sig en stigende bekymring på alle de fem områder, der er undersøgt. 
2) Man kan imidlertid også antage sig, at terrorangrebet har betydet, at man er blevet mindre bekymrede for alle de forhold, der ikke direkte forbindes med terror. Det er således muligt, at hverdagens mange bekymringer vil blegne i forhold til det, der skete d. 11. september 2001. Såfremt det forholder sig sådan, må det forventes, at der primært vil kunne ses en stigning i bekymringen for krig, men ikke på andre områder. Det er dog også muligt, at terrorangrebet forbindes med indvandrere/flygtninge og/eller med vold/kriminalitet, og at man derfor også vil se øget bekymring på dette område. Endelig kan der være nogen, der ser en vækst i arbejdsløsheden som en mulig følge af terrorangrebet, og at bekymringen for arbejdsløshed derfor også vokser. Spørgsmålet om bekymring for ventelister til hospitalerne er derimod vanskeligt at forbinde med terrorangrebet, og dette spørgsmål er da også netop taget med for at kunne afprøve denne hypotese.

3) Terrorangrebet kan dog også indirekte have medført, at danskerne er blevet mindre bekymrede for vold og kriminalitet. Vi ved, at bekymring for vold og kriminalitet i høj grad er forbundet med mediernes omtale af kriminalitet. I tiden efter d. 11. september blev forsiderne og også en stor del af de øvrige avissider ryddet, og det almindelige kriminalitetsstof, som ellers fylder en del i i hvert fald nogle aviser og medier, fyldte mindre end ellers.

4) Endelig kan det ikke udelukkes, at det ændrede spørgeskema i sig selv influerer på bekymringsniveauet, herunder især bekymringen for vold/kriminalitet. Før bekymringsspørgsmålene er der stillet en række spørgsmål om tryghed og om udsathed for kriminalitet, og dette kan medføre en konteksteffekt, eftersom andelen, der er udsat for kriminalitet og/eller føler sig utrygge, er betydeligt mindre end den, der bekymrer sig for vold/ kriminalitet. Denne konstruktion kan betyde, at færre end ellers føler sig tilskyndet til at sige, at de bekymrer sig for vold og kriminalitet, idet de jo netop har fortalt, at de føler sig trygge og ikke har været udsat for kriminalitet. En sådan konteksteffekt er set i andre undersøgelser. En kriminologisk undersøgelse fra 2001 viser således, at størrelsen af andelen, der ofte tænker på risikoen for at blive udsat for kriminalitet, afhænger af, om respondenterne forinden er blevet sporet ind på emnet. Såfremt spørgsmålet 'Hvor ofte er dette med risikoen for at blive offer for kriminalitet - dvs. blive overfaldet, udsat for tyveri, hærværk eller lignende - noget De tænker på?' bliver stillet tidligt i undersøgelsen, svarer $10 \%$ af de adspurgte, at de tænker på kriminalitet 'næsten hele tiden' eller 'ofte', mens det drejer sig om $15 \%$, når spørgsmålet stilles sidst $\mathrm{i}$ interviewet og efter, at de medvirkende er blevet spurgt om kriminalitet og politi i ca. 15 minutter (Balvig, 2001a).

\section{Danskernes bekymringer før og efter terrorangrebet}

Som figur 2 viser, er andelen, som er 'meget bekymret' for vold og kriminalitet, faldet ganske betydeligt fra målingen umiddelbart før terrorangrebet til målinger efter: fra $48 \%$ i august til $17 \%$ i oktober 2001. Samtidig er andelen, der angiver at være 'kun lidt bekymret', steget fra 15\% til 35\% og andelen 'slet ikke bekymret' fra $8 \%$ til $19 \%$. 
Det ses videre af figur 2, at en tilsvarende, men dog knap så markant tendens gør sig gældende med hensyn til bekymring for indvandrere og flygtninge. Andelen, som er 'meget bekymret', er faldet fra 35\% i august til $21 \%$ i oktober. På samme måde forholder det sig med danskernes bekymring for arbejdsløshed: et fald i andelen, som er 'meget bekymret', fra 13\% i august til 6\% i oktober. Endelig ses, at også bekymringen for ventelisterne til hospitalerne er faldet: fra $45 \%$ i august til $25 \%$ i oktober. I øvrigt viser undersøgelsen for alle de nævnte bekymringsspørgsmål, at andelen, der er 'en del' bekymret for de nævnte forhold, er ret uforandret. Det er altså andelen af 'kun lidt' eller 'slet ikke' bekymrede, der er vokset som følge af, at færre er 'meget bekymrede'. Der er på denne måde tale om ganske markante forskydninger i bekymringsniveauet.

Figur 2. Andel, der angiver at varet 'meget bekymret', fordelt efter emne og målingstidspunkt.

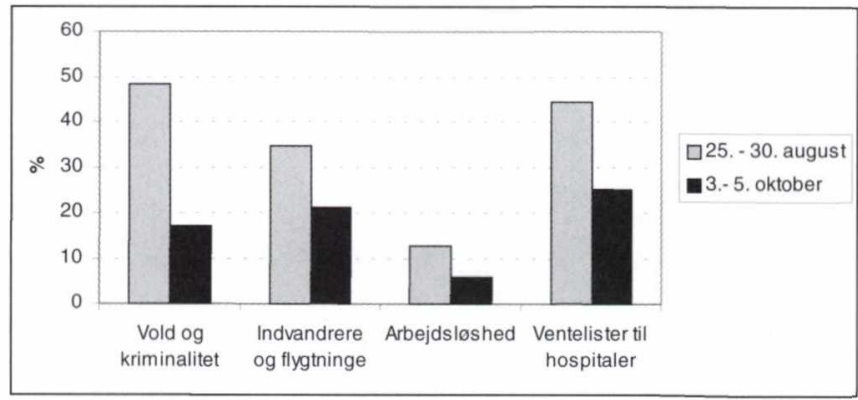

Det eneste bekymringsområde, der afviger for ovennævnte tendens, er bekymringen for faren for krig. Figur 3 viser resultatet fra undersøgelser fra henholdsvis februar/marts og oktober, eftersom dette spørgsmål ikke har med i de mellemliggende undersøgelser. I februar/marts 2001 var $8 \%$ 'meget bekymrede' for faren for krig, mens over halvdelen $(57 \%)$ angav at være 'slet ikke bekymrede' for faren for krig.

Figur 3. Bekymring for faren for krig fordelt efter målingstidspunkt.

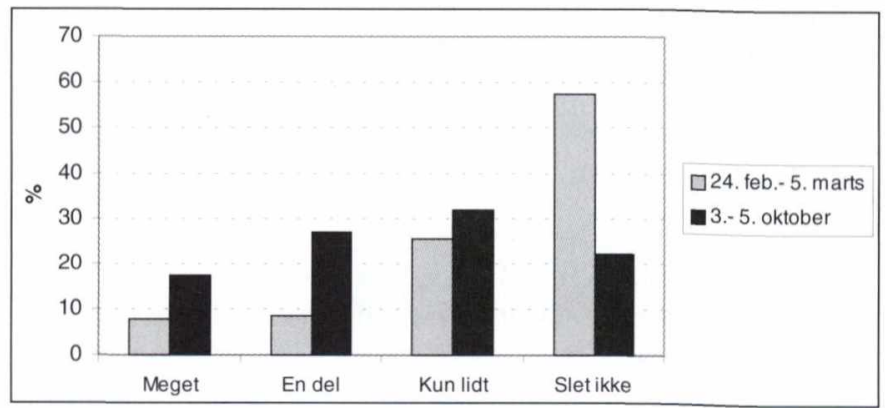


I oktober 2001 ser billedet noget anderledes ud. Nu er 18\% 'meget bekymrede' for faren for krig. Andelen, som er 'en del bekymret', er også steget betydeligt (fra $8 \%$ til 27\%), og der er også lidt flere, som er 'kun lidt bekymrede' for faren for krig. Omvendt er andelen, som 'slet ikke' er bekymrede for faren for krig faldet fra over halvdelen af de adspurgte til under en fjerdedel. Der er med andre ord i begyndelsen af oktober 2001 betydelig færre end tidligere, som aldrig bekymrer sig for krig.

Den umiddelbare konklusion på undersøgelsen synes altså at være, at først og fremmest antagelsen om, at terrorangrebet har fået hverdagens bekymringer til at blegne (hypotese 2), indfries: Danskerne er blevet mere bekymrede for faren for krig og mindre bekymret på alle andre områder. Terrorangrebet på USA den 11 . september kan altså se ud til at have haft den umiddelbare virkning, at den har flyttet danskernes opmærksomhed fra de sædvanlige hverdags- og samfundsproblemer, mens til gengæld flere end tidligere bekymrer sig for faren for krig.

\section{Mediernes omtale af kriminalstof}

Dette udelukker imidlertid ikke, at ikke også andre forhold har influeret på de forandringer i bekymringsniveauet, der ses i undersøgelsen fra oktober 2001. Den særligt kraftige ændring i bekymringen for vold og kriminalitet kan således muligvis skyldes, at også den ringe massemedieomtale af den almindelige kriminalitet har påvirket resultaterne.

Undersøgelsen fra oktober 2001 viste, at knap 1/4 af de adspurgte har været udsat for kriminalitet (tyveri, hærværk eller vold eller trusler om vold) inden for de seneste 12 måneder. Det svarer fuldstændig til resultaterne fra tidligere, tilsvarende undersøgelse (Balvig, 2001b). Bekymringen for kriminalitet stammer altså langt fra altid fra personlige oplevelser, men kan meget vel fostres af andre forhold.

Flere studier har påvist, at der er en sammenhæng mellem mediernes fokus på kriminalitet og befolkningens bekymring for kriminalitet (Balvig, 1978; Williams \& Dickinson, 1993). Når aviserne skriver meget om kriminalitet og dermed skaber et billede af, at kriminalitet er et stigende problem, vokser befolkningens frygt for kriminalitet ${ }^{\prime}$. Mediernes fokus på kriminalitet afspejler ikke kriminaliteten i samfundet, hverken hvad volumen eller indhold angår (Sacco, 1995). Mediernes dagsorden er at præsentere historier med stor 'nyhedsværdi', hvorfor vold i særdeleshed kommer i fokus (Funkhouser, 1973). Kriminalstoffet kan desuden bruges som en slags 'buffer', som kan fylde den resterende spalteplads op i avisen, når der ikke er andre interessante nyheder (Sacco, 1995). Hvor stor en del kriminalstoffet får lov at fylde i avisen, afhænger derfor af, hvilke andre begivenheder der er sket, som avisen finder det interessant at skrive om.

Der er imidlertid også forskel på, hvordan forskellige aviser behandler kriminalstoffet. Undersøgelser viser, at formiddagsaviser indeholder flere og længere artikler om vold og kriminalitet, end morgenaviser gør. Desuden fremstiller formiddagsaviserne historier om kriminalitet mere sensationelt og ledsager oftere historierne med billeder, end morgenaviserne gør (Williams \& Dickinson, 1993; 
Laursen 2001). Undersøgelserne viser også, at de, der læser formiddagsaviser, er mere utrygge end dem, der læser morgenaviser. Det kan imidlertid diskuteres, hvordan sammenhængen skal forstås: Om det er er læsningen af formiddagsaviserne, som skaber frygten for kriminalitet, eller om det er dem, der i forvejen er bange for kriminalitet, som vælger netop den type avis, fordi den svarer til deres opfattelse af virkeligheden.

Nogle teoretikere peger imidlertid på, at antallet af kriminalitetshistorier i avisen ikke betyder så meget i forhold til at skabe frygt i befolkningen (fx Liska \& Baccaglini, 1990). Det afgørende for, om historierne om kriminalitet skaber frygt $i$ befolkningen, er afstanden til den kriminalitet, der berettes om. Kriminalitet i ens lokalområde skaber frygt, mens kriminalitet, som er længere væk, fx i andre byer, kan have den modsatte effekt ('safe by comparison'). Hvis kriminaliteten er foregået i ens nærområde, får man i højere følelsen af 'at det kunne have været mig', end hvis det er er foregået flere kilometer væk.

Af ovenstående følger, at man må forvente, at læsere af formiddagsaviser (som indeholder meget kriminalstof) og lokalaviser (som indeholder meget lokalstof også om kriminalitet) er mere bekymret for vold og kriminalitet, end læsere af morgenaviser er.

Efter den 11. september fik kriminalstoffet som nævnt en mindre fremtrædende position i massemedierne. Hvis der er sammenhæng mellem kriminalstof $i$ avisen (mængden af artikler, præsentation og placering af stoffet) og bekymring for vold og kriminalitet hos avislæseren, må det forventes at betyde en forholdsvis større mindskning i andelen af meget bekymrede hos læserne af formiddags- og lokalaviser end hos læserne af morgenaviser.

Denne antagelse synes at blive bekræftet i undersøgelsen. Som det ses af figur 4, er andelen af 'meget bekymrede' avislæsere af landsdækkende morgenaviser faldet med 20 procentpoint fra august til oktober, mens faldet for formiddags- og lokalaviserne er på $37^{2}$. Faldet er altså størst hos læsere af de medier, der sædvanligvis fokuserer mest på kriminalitet.

Figur 4. Andel, der er 'meget bekymret' for vold og kriminalitet, fordelt efter avistype og målingstidspunkt.

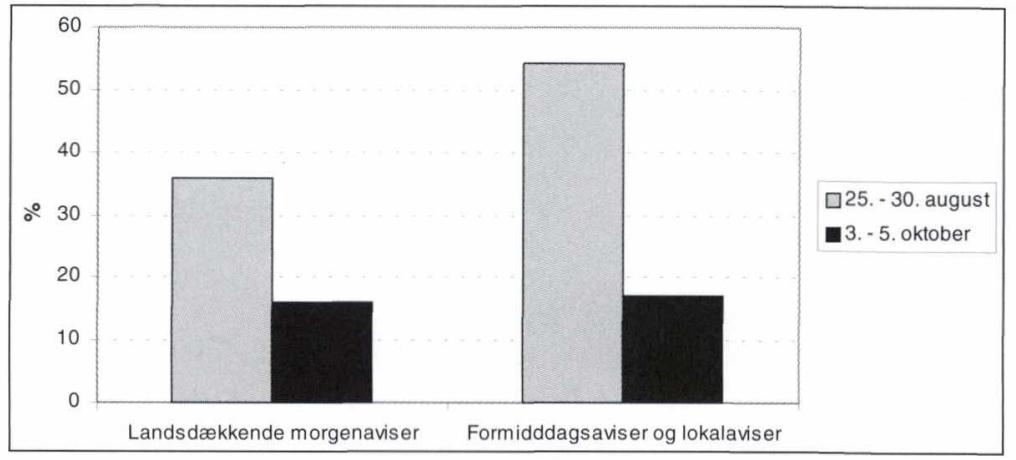




\section{Konteksteffekt}

Selv om undersøgelsen kan tyde på, at både en blegningseffekt og en mindsket fokusering på almindelig kriminalitet i massemedierne kan have influeret på faldet $\mathrm{i}$ danskernes bekymring for især vold og kriminalitet, udelukker det ikke, at ændringen i bekymringsniveauet fra augustundersøgelsen til oktoberundersøgelsen ikke også er påvirket af det ændrede spørgeskema - af at spørgsmålene om bekymring indgår i en ny kontekst.

Spørgeskemaet i oktoberundersøgelsen indeholdt en række spørgsmål om bl.a. tryghed, og denne del af undersøgelsen har vist - i lighed med andre tilsvarende undersøgelser - at de fleste af respondenterne føler sig trygge. ${ }^{3}$ Såfremt respondenternes svar på tryghedsspørgsmålene påvirker svarene på bekymringsspørgsmålene, er der tale om en konteksteffekt. En sådan konteksteffekt må formodes at have størst betydning for spørgsmålet om bekymring for vold og kriminalitet, eftersom det er tematisk nært beslægtet med tryghedsspørgsmålene.

Konteksteffekt er fundet i mange - primært udenlandske - undersøgelser, mens det sjældent er noget, danske forskere eksplicit forholder sig til ved udarbejdelsen af spørgeskemaundersøgelser. I metodebøger står ofte nævnt, at man skal passe på faren for konteksteffekt, men der gives sjældent gode råd til, hvordan det undgås. Som Henning Olsen - én af de danskere, der har beskæftiget sig med emnet - skriver: “...mange surveyforskere er tilsyneladende af den opfattelse, at sprogbrug er som åndedræt: At mestre statistiske metoder fordrer tilegnelse af viden herom, men at mestre (survey)sproget er åbenbart alle forskere beskåret " (Olsen, 1998:70). Forskerne bruger med andre ord en masse energi på at analysere data, men sjældent megen energi på at udforme det spørgeskema, dataene er baseret på.

Det er vanskeligt at forudsige konteksteffekters art og omfang. Forskellige undersøgelser har registreret konteksteffekter på mellem 13-17\%, det vil sige, at svar på spørgsmål varierer med op til $17 \%$ afhængig af, hvilken kontekst spørgsmålene indgår i (fx Schuman, Presser \& Ludwig, 1981).

Konteksteffekter opstår, fordi forbindelsen mellem spørgsmålene i et spørgeskema danner en mental ramme, som respondenten benytter, når denne besvarer spørgsmålene. Spørgeskemaets kontekst virker med andre ord som en tavs baggrundsforståelse. Det betyder, at respondenten ikke besvarer spørgsmålene, som var de separate og uafhængige spørgsmål, men som var de en række af sammenhængende spørgsmål. Respondenten har derfor de tidligere spørgsmål og afgivne svar in mente ved besvarelsen af efterfølgende spørgsmål. Risikoen for konteksteffekt er størst ved holdningsspørgsmål, og såfremt spørgsmålene er tematisk beslægtede (Olsen, 1995 og 2001).

En type konteksteffekt betegnes som overførsel. Overførsel sker fx når et specifikt spørgsmål placeres før et generelt spørgsmål. Ved det efterfølgende 
generelle spørgsmål tager respondenten for givet, at der stadig spørges til det specifikke emne - og svarer i overensstemmelse med dette. Overførsel kan også forekomme, når respondenter forsøger at skabe konsistens ved besvarelsen af spørgsmålene. En sådan konsistenseffekt er med andre ord en situation, hvor respondenten tilpasser sine svar, så disse stemmer overens med besvarelsen af de tidligere spørgsmål (Olsen, 2001).

For at undersøge, om faldet i bekymringsniveauet fra august til oktober kan skyldes konteksteffekt, bad vi IfKA om at medtage tryghedsspørgsmålene fra oktoberundersøgelsen i deres ordinære kvartalvise decemberundersøgelse (interviewene gennemført 24.-29. november), men denne gang alene stille disse spørgsmål til halvdelen af respondenterne ${ }^{4}$ Eventuelle forskelle i bekymringsniveauet mellem de respondenter, der har fået stillet bekymringsspørgsmålene, og dem, der ikke har, må så antages at skyldes kontekstforskelle.

Resultaterne af decemberundersøgelsen tyder i allerhøjeste grad på, at en konteksteffekt har gjort sig gældende. De respondenter, som har fået stillet tryghedsspørgsmål før bekymringsspørgsmålene, er således generelt mindre bekymrede end dem, der ikke har fået stillet tryghedsspørgsmål. Som figur 5 viser, gælder det i forhold til alle typer bekymringer ${ }^{5}$.

Figur 5. Andel, der angiver at vare 'meget bekymret', fordelt efter emne og om målingen inkluderer tryghedsspørgsmål.

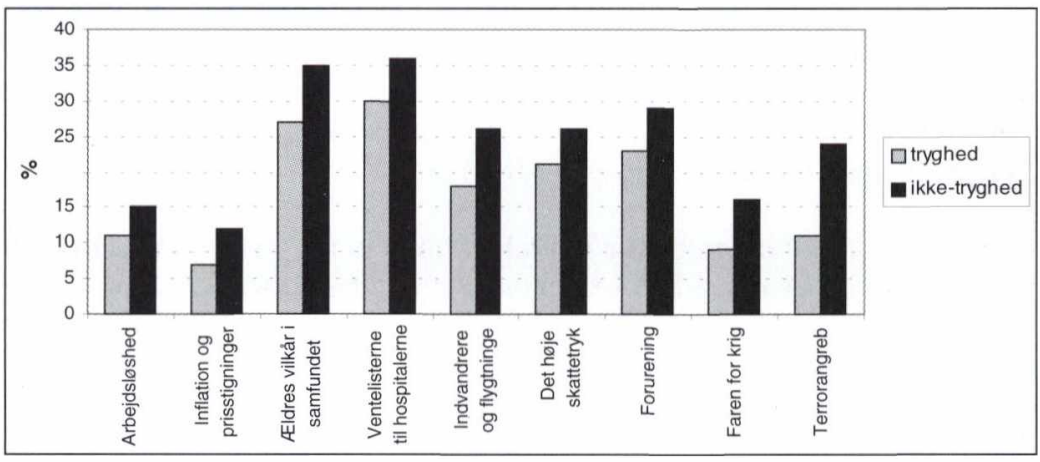

Forskellen i bekymringsniveau er dog, jf. figur 6, størst for Bekymring for vold og kriminalitet. Mens 38\% af respondenterne svarer, at de er 'meget bekymrede' for vold og kriminalitet, når de ikke er blevet spurgt om tryghed, drejer det sig om $20 \%$, når de forinden er blevet spurgt om tryghed. Inddragelsen af tryghedsspørgsmålene betyder altså, at hele $18 \%$ af respondenterne svarer anderledes på spørgsmålet om Bekymring for vold og kriminalitet. Forskellen er statistisk signifikant (p-værdi på 0,00 ved chi2-test). 
Figur 6. Svarfordeling for Bekymring for vold og kriminalitet fordelt efter om målingen inkluderer tryghedsspørgsmål.

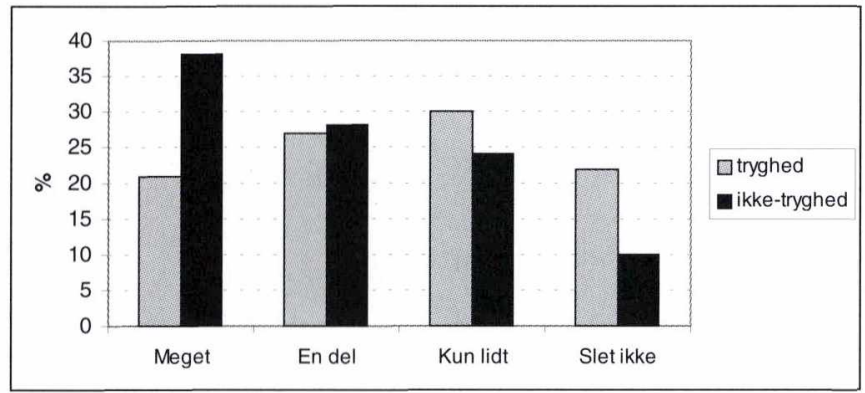

\section{Diskussion og konklusion}

Den fortsatte undersøgelse har tydeligt vist, at den første, umiddelbare tolkning af ændringen i bekymringsniveauet fra før til efter terrorangrebet på USA ikke er holdbar. Det, der umiddelbart kunne se ud som en uskyldig og forholdsvis minimal ændring af det anvendte spørgeskema, synes at have haft en overordentlig stor betydning for udfaldet af oktoberundersøgelsen. Det forandrede bekymringsniveau er i hvert fald ikke alene et produkt af terrorangrebet og dets afledte virkninger, men også et kunstprodukt af et ændret spørgeskema.

Det interessante spørgsmål er imidlertid, om hele faldet i bekymringsniveauet skal tilskrives en konteksteffekt, eller om en blegningseffekt og/eller mediernes koncentration om denne begivenhed også har haft en betydning. Noget taler for, at sidstnævnte er tilfældet.

Figur 7. Andel, der er 'meget bekymret' for vold og kriminalitet, fordelt efter målingstidspunkt og om målingen inkluderer tryghedsspørgsmål. Med sikkerhedsintervaller.

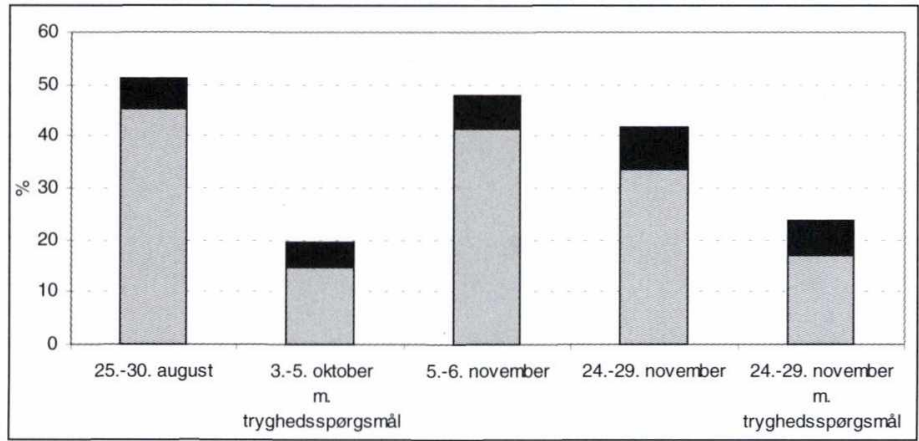


Decemberundersøgelsen (gennemført 24.-29. november) viser som sagt, at konteksteffekten bevirker et fald $\mathrm{i}$ andelen af 'meget bekymrede' på 18 procentpoint (med sikkerhedsintervaller: min. 9,8, max. 25,0). Som det ses af figur 7 var faldet $i$ andelen af 'meget bekymrede' imidlertid betydeligt større fra august- til oktoberundersøgelsen, nemlig på hele 31 procentpoint $\left(\min .25,3\right.$ og max. 36,1). ${ }^{6}$ Det tyder altså på, at det ikke alene er det ændrede spørgeskema, der har påvirket faldet $\mathrm{i}$ bekymringen for vold og kriminalitet. På baggrund af de øvrige undersøgelser, der har målt en konteksteffekt, forekommer det i øvrigt ikke særlig sandsynligt, at konteksteffekten i denne undersøgelse skulle overstige 20 procentpoint.

Det skal bemærkes, at et mønster, som det, der er vist i figur 7, også gør sig gældende for bekymringen for arbejdsløshed og bekymringen for indvandrere og flygtninge - om end i en mindre markant form. Dvs. at faldet i bekymringen fra august- til oktoberundersøgelsen næppe heller på disse områder udelukkende kan forklares med en konteksteffekt.

Samlet set tyder undersøgelsen altså på, at terrorangrebet på USA umiddelbart har indebåret, at danskernes mere almindelige og hverdagsagtige bekymringer for forskellige samfundsanliggender er trådt noget $\mathrm{i}$ baggrunden $\mathrm{i}$ forhold til den kolossale og dramatiske begivenhed i USA. Muligvis har mediernes koncentration om lige netop denne begivenhed også haft en betydning for, at bekymringen for andre forhold generelt synes at have været mindre i perioden lige efter terrorangrebet.

I et lidt videre perspektiv tyder undersøgelsens påvisning af en kraftig konteksteffekt på, at 'bekymring' er en noget foranderlig og let påvirkelig størrelse. Sammenlignet med den konteksteffekt, der er fundet i den ovennævnte danske kriminologisk undersøgelse, er den, der her er fundet, betydeligt større, ligesom den viser sig på områder, der ikke umiddelbart er nært tematisk beslægtede med emnet tryghed. Den påviste blegningseffekt tyder samtidig på, at bekymring er en relativ og ikke en absolut størrelse, og at markante samfundsbegivenheder kan flytte bekymringens fokus.

Målinger af befolkningens bekymring for vold og kriminalitet må på denne baggrund antages at give et mere usikkert og ustadigt indtryk af forekomsten af personlig ængstelse, frygt eller angst for kriminalitet end andre typer af målinger, herunder sådanne, der vedrører personens tryghedsoplevelse. Som tidligere nævnt viser de undersøgelser, som er blevet foretaget vedrørende befolkningens tryghed, netop - og uanset terrorangreb - et ganske stabilt niveau.

\section{LITTERATUR:}

Balvig, Flemming: Angst for kriminalitet. Gyldendal, København. 1978.

Balvig, Flemming: Det nare politi - 2 ar efter: Rigspolitiet, København. 2001a.

Balvig, Flemming: 'Kriminaliteten i Danmark - i europaisk perspektiv'Juristen nr. 7. 2001b.

Funkhouser, G. Ray: 'The Issues of the Sixties: An Exploratory Study in the Dynamics of Public Opinion' Public Opinion Quarterly 37:62-75. 1973. 
Laursen, Søren: Vold på dagsorden. Medierne og den politiske dagsorden. Magtudredningen, Århus 2001.

Liska, Allen E. \& William Baccaglini: 'Feeling Safe by Comparison: Crime in the Newspapers' Social Problems 37:360-374. 1990.

Olsen, Henning: 'Det mindst ringe spørgeskema?' Dansk Sociologi nr. 1., 9. årgang:63-84. 1998.

Olsen, Henning: Sprogforståelse og hukommelse i danske surveyundersøgelser. Bind 1 og 2. Socialforskningsinstituttet, København 2001.

Olsen, Henning: Tallenes talende tavshed. Socialforskningsinstituttet, København 1995.

Sacco, Vincent F.: 'Media Constructions of Crime' The Annals of the American Academy 539:141154. 1995.

Schuman, Howard et al: 'Context Effects on Survey Responses to Questions About Abortion' Public Opinion Quarterly 45:216-223. 1981.

Williams, Paul \& Julie Dickinson: 'Fear of Crime: Read All about it?' British Journal of Criminology 33:33-56. 1993.

Noter:

' Det bemærkes, at udenlandske undersøgelser beskæftiger sig med 'fear of crime', mens IfKA spørger om folks 'bekymring for vold og kriminalitet'.

${ }^{2}$ Morgenaviser (landsdækkende): Berlingske Tidende, Information, Jyllands Posten, Kristeligt Dagblad og Politiken. Formiddags- og lokalaviser: B.T., Ekstra Bladet, Fyens Stiftstidende, Jydske Vestkysten, Nordjyske Stiftstidende, Århus Stiftstidende og andre hverdagsaviser.

${ }^{3} 74 \%$ tænker aldrig eller sjældent på risikoen for at blive offer for kriminalitet, mens $15 \%$ tænker på risikoen 'af og til'. 98\% føler sig aldrig eller sjældent utrygge ved at færdes alene i deres lokalområde i dagslys. $81 \%$ føler sig aldrig eller sjældent utrygge ved at færdes alene i deres lokalområde, når det er mørkt. $94 \%$ føler sig aldrig eller sjældent utrygge ved at færdes alene uden for lokalområde i dagslys, og $68 \%$ føler sig aldrig eller sjældent utrygge ved at færdes alene uden for deres lokalområ$\mathrm{de}$, når det $\mathrm{er}$ mørkt.

${ }^{4}$ Foruden de bekymringsspørgsmål, som var med i oktober-undersøgelsen (dvs. vold og kriminalitet, indvandrere og flygtninge, arbejdsløshed, ventelisterne på hospitalerne og faren for krig), er respondenterne i december-undersøgelsen også blevet spurgt, om de er bekymrede for inflation og prisstigninger, celdres vilkår i samfundet, det høje skattetryk, forurening og terrorangreb.

${ }^{5}$ Sammenhæng mellem bekymringsniveau og tryghedsspørgsmål eller fravær heraf er statistisk signifikant for alle bekymringsspørgsmål med undtagelse af Bekymring for det høje skattetryk, hvor pværdien er 0,10 ved en chi2-test.

${ }^{6}$ Ved siden af de ordinære målinger har IfKA - i forbindelse med folketingsvalget i november - gennemført en ekstra måling d. 5.-6. november. Denne er omfattet af figur 7.

\section{Adresse: Justitsministeriet}

Slotsholmsgade 10

1216 Kbh. K. 